\title{
A CARACTERIZAÇÃO DO ESPAÇO EM "O DELFIM"
}

\author{
JURIL DO NASCIMENTO CAMPELO \\ (Professora de Literatura Portuguesa da Universidade \\ Federal do Paraná)
}

A primeira vista, o texto de José Cardoso Pires parece dispor os espaços dentro da ótica vigorante na estética neo-realista. Tanto a Gafeira, como a casa da Lagoa, enquanto espaços, estăo impregnados de sentido social $\theta$ se vinculam claramente à oposiçăo abundância-miséria.

A leitura poderia conduzir apenas ao sentido de denúncia de injustiças sociais se, da oposiçāo inicial identiflcável, não decorressem oposições menores: beleza-ausência de beleza, ociosidade-trabalho, privacidade-socializaçāo. Estas oposiçōes, ainda que semanticamente aparentadas entre sì, operam em diferentes niveis de significação e contribuem para que a dissolução do espaço da abundância (a casa da Lagoa) não opere na narrativa a redenção do espaço da miséria (Gafeira).

Além disso, percebe-se que o discurso de 0 Delfim foge da tendência à reduplicação do código, tāo freqüente nas obras neo-realistas, e se comporta em alguns aspectos como o modelo do novo-romance; efetivamente, 0 Delfim rompe com o discurso linear e instaura um sentido alegórico, a par do significado ético-ideológico ao qual se propōe. A ironia torna-se o recurso preferido pelo narrador nesta caminhada.

O texto ultrapassa, portanto, a temática da patologia social para que o romance possa construir-se voltado para a su própria estrutura.

Examinando a Gafeira e a casa da Lagoa, notamos que esses dois espaços se acham lingülsticamente diferenciados por inscrições latinas que 
afirmam o sentido de cada espaço e o patronato de uma autoridade.

"Isidi Donin/M. Oct. Lib. Theophilus"

é a inscriçāo da muralha da aldeia, e

"Ad Usum Delphini".

é a inscrição imaginária,

"A meio da arcada, de preferēncia, e na boa cantaria" (p. 63) na casa da Lagoa. Além de constituírem um apelo ótico e estético, as legendas possuem a propriedade de interdição reciproca dos espaços, tal como o totem nas civilizações primitivas, o estandarte nas legiões, a bandeira nas naçōes.

“Lagoa e Palmas Bravo fazem uma e a mesma história' (p. 162). A fusão entre proprietários e propriedade é perfeita, traduzindo um mimetismo existencial que se projeta como verossimil até no diferente.

A descrição da casa da Lagoa é pontilhada de "sinais de casta", como "cobres nas paredes, uma espingarda antiga em cima da lareira",

há revistas francesas espalhadas pela sala, bebidas raras, móveis requintados, cães de fina raça, automóvel importado. O esnobismo do Engenheiro revela-se como necessidade de hierarquizaçāo dos espaços que o cercam.

O casal Palma Bravo é um recorte deste mesmo espaço: "E eles avançando de cabeça levantada, māo na mão, sem um cumprimento a quem quer que fosse $/ . . . /$. Duas silhuetas de moeda, dois infantes do meio dia". (p. 26).

A vila apresenta espetáculo diverso: "Vejo interiores de casebres alumiados a petróleo /.../. Num ou outro há o gato e a criança de bariga nua e de pernas arqueadas; num ou noutro há o cachorro e a galinha presa pela pata auma cadeira e em grandes alguidares de folha remexem enguias pardacentas"'. (p. 223)

Envolvendo os dois espaços fulcrais da narrativa, há uma densa névoa outonal. Na vila é o fumo das enguias que dissimula a realidade. "Nesta estaçāo, Gafeira, pressente-se vida, mas custa a distinguir através dos vidros, tal é o fumo. Há música saida de um alpendre (?) e bicicletas em linha, $\theta$, a toda volta, manchas imprecisas, população, habitações, ruas". p. 261) $\mathrm{Na}$ lagoa, outra espécie de bruma: "Lá está a nuvem, a coraa a desenhar-se por cima do pinhal". (p. 169) E a evaporaçăo permanente, que marca, à distância, e de forma heráldica ("coroa") a situaçăo da lagoa. A bruma afirma o caráter misterioso do relato. "E nós escalando o monte, e a bruma a fechar-nos o caminho atrás dos passos", (p. 319) como se a bruma encobrisse o passado das personagens. 
A descriçāo do largo da Gafeira, no início, contém: "tal como um prado de cardos, mostra-se agressivo, só domável ao tempo; o se năo pica, repele, servindo-se das covas, dos regos das chuvas ou da poeirada dos estios". O narrador apresenta-o como espaço hostil, que "repele", embora assinale o passado alegre, quando o largo servira de arraial e feira e a vida da aldeia ali palpitava. "Antigamente, cinqüenta, setenta anos atrás o terreiro foi com certeza uma praça de feira, porque năo? Um arralal". (p. 16) "/.../ Pois sim, mas agora o largo é o que se vê. Uma muralha, um espectro". (p. 18) o ambiente da casa da Lagoa, no tempo anterior à tragédia, ao contrário do largo, acolhe. Apresenta caça e pesca abundantes, casa confortável e a bebida sempre à espera do anfitrião e de seu companheiro.

A medida que o dia avança, e com ele a descoberta da tragédia, do abandono da casa da Lagoa e que os fragmentos de lembrançs vão se montando junto com os cortes do momento presente, como um mosaico, as classificaçōes caracterizadoras dos dois espaços vāo se transformando. A altura da metade do livro, lê-se: "Ao fim da tarde o largo perdeu o ar agressivo, é um território de abndono que acaba de cumprir mais uma jornada /.../. Dentro em breve vai render-se à noite, que é a face comum do universo $1 \ldots /$. Confundir-se, enfim, com a mesma mancha que iguala outras zonas fellzes /.../:" (p. 193) Verificamos, deste modo, que o avanço do tempo do discurso, e o cumprimento da medida dramática aristotélica das vinte e quatro horas fazem com que se opere a fusão dos espaços dicotômicos em um tempo-espaço neutro: - a noite. Deixa de haver a clara oposição sim/não (cf. Introdução), para se registrar a prevalência da unidade mascarada simnão.

"Ao anoitecer, o halo derramava-se e tudo indicava que era a despedida, que decididamente a lagoa se la desligar da aldela. Mas não, acto contínuo tilintavam campainhas, dezenas de camponeses-operários regressavam da Vlla nas suas bicicletas, e essa música falava-me de cestos de engulas arrancadas às águas de madrugada, em rápidas surtldas na viagem para as fábricas". (p. 131)

A insistência com que o tema hídrico aparece no romance chega a ser abcecante. Desde as primeiras linhas sua importância é assinalada: “... vejo o largo, a estrada de asfalto e um horizonte de pinhais dominado por uma coroa de nuvens: a lagoa $/ . . . /$ (o Autor) Sente vida por baixo e à volta dele. sim, pode senti-la, mas por enquanto, fixa-se unicamente, e com intenção, no tal sopro de nuvens que é a lagoa". ( $p .10)$

As águas da Lagoa na narrativa de O Delfim constituem um espaço pecullar com função de economia, de saúde, de lazer, de liberdade e de mor- 
te. Espaço mitico por excelência, já na Monografla a Lagoa surge com a valorizaçāo que se irradiará por toda a narrativa: "/..." águas boas na cura das feridas malignas e de abundante e saboroso pescado". (p. 18) Foram as termas romanas instaladas por Teófilo que corromperam a Gafeira, segundo o Abade Saraiva, e por isso a maldição pesa sobre o lugar.

Curioso é notar que a lagoa reúne em si uma série de imagens em diforentes planos: peixes mortos incólumes no lodo do fundo, engulas em águas menos profundas, adens, marrecos na superfície, e uma nuvem em forma de "coroa" acima da superfície. O narrador nos apresenta esta visāo em "corte transversal", o que nos possibilita examinar as mültiplas "camadas" da realidade inerente à lagoa. Para maior esclarecimento sobre a situação exata, além das descrições do texto, algumas ediçōes (Moraes) apresentam o mapa da regiāo na contra-capa do livro.

A dupla participaçāo da água no texto, como vida e como morte, já se encontra em estado de latência no texto-encaixe do Abade Saraiva, que citamos há pouco. Além disso a água, no texto, nāo se contenta em ser apenas ela mesma, mas procura entrar em composição com os outros très elementos vitais: com o ar ao formar a nuvem permanente acima do pinhal, com a terra quando institui o lodo e com o fogo no momento em que os caçadores atiram das margens, e as águas se adensam com a pólvora ("a lagoa queima, a lagoa queima" (p. 42).

Assim, as imagens nascidas da água neste texto sāo de diferentes consistências: a nuvem. a bruma, permanece como um espaço impalpável, halo de mistério que atrai o narrador para a Lagoa. Vimos que as enguias ao serem preparadas na Vila desprendem um denso fumo que de certo modo continua a bruma da lagoa; o lodo (miraculoso, pois tem propriadade de conservar cadáveres) é o espaço mesomorfo por excelência. "On peut en effet, salsir une sorte de coopération de deux éléments imaginaires, cooperation pleine d' incidents, de contrarietés selon que l'eau adoucit la terre ou que la terre apporte à l"eau sa consistance " 1 " a famosa massa da lagoa composta de lodo e de baba de peixe" que a Monografla apregoa como remédio dos antigos contra as chagas da lepra. E como matéria de luxúria" (p. 358-59).

O fogo associa-se claramente à caça na lagoa "A fusilaria rompe ato contínuo sobre uma cortina de asas que explode e se levanta do areal em todas as direçōes, metralhada por um burburinho de caçadeiras...

Sinto a lagoa inebriada, cheirando a pólvora" (p. 350-51)

A água como elmento isolado, ou em comblnação com os outros três, afirmará por toda a trajetória da narrativa a relaçāo axial vida/morte (sim/ nāo).

O aspecto vida é representado pelo sentido de criatura que dá a vida e 
nutre com sua substância, imagem humanizada, que corresponde sem dúvida à entidade materna.

"Lagoa para a gente daqui, quer dizer coração, refúgio da abundância. Odre. Ilha. Ilha de água cercada de terra por todos os lados e por espingardas de lei.

Mas ilha, odre, coroa de fumos ou constelação de aves, é a partir dela que uma comunidade de camponeses-operários mede o universo" (p. 129). O caráter feminino e a capacidade de criar da lagoa são afirmados por uma longa metáfora, em que o mar é representado como esposo e o lodo tornase o útero da mulher-mãe revirginizada (vemos aí uma relaçāo cósmica com o arquétipo mäe-divina).

Todos os anos o mar rasga a membrana de arela que corta a linha das ondas, insinua-se nela penetra por esse corredor e carrega sobre a lagoa, fecundando-a de vida nova. 0 ventre amplo, ventre macio forrado de lodo, revolve-se, transborda, mas passado o impeto, povoa-se de pequeninas centelhas de cauda a dar e a lagoa fica majestosa e tranqülla como um odre luminoso de peixe abandonado no vale, entre pinhais. (p. 161)

Mas nāo é só positivo o significado da lagoa, desaparece a disjunçāo $\mathrm{sim} /$ năo quando é afirmado o significado negativo da lagoa, e o texto cria, também aí, uma conjunçāo de contrários:

Claro que há o lado mau, claro que sim. Durante anos e anos a lagoa acumulou tais venenos, de matar peixes, suportou tanta pólvora e tanta autoridade que - limito-me a repetir o Regedor - queima quem se atreva a ofendê-la. Razão por que, dentro da boa lógica, se prepara para devorar a casa dos Palmas Bravo /.../; razāo por que desafia de longe os mastins do Engenheiro e assiste, impassivel à loucura que se val apossando deles; razāo, por último, do abraço de morte com que recebeu Maria das Mercês na madrugada de 12 de malo próximo passado. (pp. 133-34).

Notamos, que ao sublinhar o "lado mau" da lagoa, o narrador cobre-a com imagens ligadas ao fogo (no sentido de destrulçăo). De mãe generosa, a lagoa transforma-se em inimiga vingativa, uma espécie de inferno liquido que traga os que "se atrevem a ofendé-la".

Além da carga poética contida no signo Lagoa, por representar dols temas oponivels do consciente, 0 da vida e o da morte, destaca-se do texto um tratemento Irônico, de nivel caricatural, no momento em que o narrador confere 
ao pai do Engenheiro o mal da hidropisia. "O fidalgo tanto bebera que acabara afogado na própria barriga". (p. 173) Em seguida, em um rasgo motadiscursivo, passa a analisar a doença imputada ao velho Palma Bravo (verdadeira alegoria maneirista ao estilo de Bosch) em relação ao caráter verossímil da narrativa. Utiliza, para tanto, um parágrafo parentético, transbordante de ironia:

(Em principio, sim. Uma hidropisia é na verdade, um exagero, uma caricatura da morte. Nenhum narrador eficaz cairia nessa armadilha, nessa escolha, tão espaventosa no catálogo das doenças possiveis. Não lembra ao diabo uma lagoa vingar-se tão teatralmente instalando-se na barriga de um rei condenado. Mas nảo tem importância. No principio era a água, e água estava nele... Ofendi, zeloso Abade? Posso continuar?) (p. 173)

Vê-se, na transcriçāo, a paródia da verossimilhança e do texto biblico do Gènesis: o narrador, ao mesmo tempo que utiliza a água como elemento simbólico, representativo do sentido da personagem, analisa o processo utilizado do ponto de vista do receptor (leitor), isto é, como coincidència forçada. Esta passagem ao desvendar com ironia o seu narrar, consegue reforçar a simbologia da água enunciando a intencionalidade da mesma.

A morte do pai Palma Bravo por hidropisia encontra o equivalente formal na morte de Maria das Mercês por afogamento. Este "paralelismo hídrico" amarra os dois passados da narrativa: o passado remoto, anterior à presença do narrador na Gafeira, ao passado próximo, narrado por evocação. As relaçōes da Lagoa com o tempo, com o espaço e com as personagens superativam o elemento hidrico, que rege a narrativa. Pode-se dizer que a vida $e$ a morte estäo garantidas pela água.

Também o romance, enquanto discurso sobre as açōes interpoladas entre esses dois limites, é decorrência do elemento hídrico-Lagoa, e corresponde, metaforicamente, à caça aos patos. por se tratar de uma caça à verdade dos fatos e de uma busca de plenitude do ato literário em si.

\section{REFERENCIAS BIBLIOGRAFICAS}

BACHelard, Gaston. La terre et les rêveries de la volonté. - 6 ed. Paris. José Corti, 1948. D. 74 .

FREUD, S. Totem e tabr. Rio de Janeiro, Ed. Guanabara, s.d. 283 p.

PIRES. J. C. O Delfim. 5." ed. Lisbon, Moracs, 1972. 363 p. 